\title{
O PROBLEMA JURÍDICO DOS TRANSGÊNICOS NA LEGISLAÇ̃̃O BRASILEIRA
}

\author{
Giselda Maria Fernandes Novaes Hironaka \\ Professora Associada do Departamento de Direito Civil \\ da Faculdade de Direito da Universidade de São Paulo. \\ Fernando Curi Peres \\ Ph.D. pela Ohio State University e Professor Titular de \\ Economia e Administração da Escola Superior de \\ Agricultura Luiz de Queiroz da Universidade de São \\ Paulo.
}

Resumo:

A excelente performance do agronegócio brasileiro está ameaçada por limitações impostas ao uso de organismos geneticamente modificados (OGMs) e, principalmente, à pesquisa a eles relacionada. O trabalho descreve, inicialmente. a recente história judicial e legislativa sobre o uso comercial de OGMs e conclui com a indicação de que, apesar das decisões judiciais que proibem o plantio e comercialização da soja round up ready serem dotadas de plena eficácia jurídica, o que se observa é sua não efetividade, uma vez que os agricultores têm utilizado amplamente a tecnologia. Do ponto de vista da economia, o trabalho mostra que as sugestões de que o uso e pesquisa com transgênicos resultarão em prejuízos ao ambiente e à saúde humana não resistem a uma análise objetiva e que as eminentes catástrofes previstas pelo seu uso não têm se verificado na prática, apesar de já estarem sendo utilizadas comercialmente por mais de dez anos em grandes áreas plantadas.

\section{Abstract:}

The excellent performance of the Brazilian agribusiness is being treated by limitations imposed on the commercial use and on researching with genetically modified organisms (GMOS). Initially the study describes the recent history of the legal contest between the pro and against GMOs' use and concludes indicating that although the judiciary clearly indicate that round up ready soybean crop is legally forbidden, farmers are using the technology in large scales in some cases. From an economic perspective, the study shows that suggestions that the commercial use of GMOs will cause serious damages to the environment and to human health do not stand to objective analyses. Furthermore, the eminent environmental catastrophes that would follow its commercial use is not being observed even thought a large proportion of areas are being cropped in some countries, for a long time span, with GMOs.

Unitermos: OGMs; uso comercial de OGMs; pesquisa com OGMs; indução de mutações; indústria química; Lei de Biossegurança; Comissão Técnica Nacional de Biossegurança (CTNBio); Estudo de Impacto Ambiental 
(EIA); Relatório de Impacto no Meio Ambiente (RIMA); princípio da precaução; rotulagem transgênica.

Keywords: GMOs: GMOs' commercial use; GMOs'research; mutations induction; chemical industry; Bio-safety low; National Technical Commission on Bio-safuty (CTNBio); Environmental Impact Report (RIMA); precaution principle; transgenic labeling.

\section{Primeiras palavras}

O agronegócio brasileiro tem tido uma performance excelente nas últimas décadas, podendo ser responsabilizado por expressivos ganhos de renda ou de bem-estar para a população brasileira. Por meio de sua maior eficiência - refletida numa maior oferta dos seus produtos tanto à população nacional, como a outros países, a preços declinantes - o setor tem gerado rendas, empregos e as tão necessárias divisas que o Brasil precisa, para continuar crescendo e se desenvolvendo.

Como em quase todas as áreas do conhecimento o das atividades humanas, a interface do Direito com as atividades do chamado agronegócio forma um conjunto muito grande de possíveis interações, o que proporcionou, aos autores deste estudo, a possibilidade de particularizar um subconjunto específico, dentro deste universo interdisciplinar, visando exatamente dar tratabilidade prática ao tópico. Afinal, o verdadeiro embate nacional que se travou em torno do uso dos organismos geneticamente modificados .. ou transgênicos, como se os tem costumeiramente denominado - torna-os um vigoroso foco de interesses voltados ao seu tratamento, quer do ponto de vista jurídico, quer do ponto de vista iconômico, tudo em razão das conseqüências que as políticas, as leis e as diretrizes que regularão o seu uso poderão se fazer sentir na continuação ou na interrupção do desempenho do agronegócio nacional.

A interface entre os dois campos analiticos na questão dos transgênicos

a jurídica e a técnica - tem se mostrado em alta exposição nos meios de comunicação. Esta intensa discussão na mídia gerou um grau de participação popular nos debates que. inevitavelmente. acabou por permitir a transferência de aspectos ideológicos para o centro das argumentações. Acirraram-se as discussões cm tal nível que se percebe. com clareza, que se encontram ameaçadas, ou impedidas, não só a possibilidade do agronegócio brasileiro usar certas tecnologias já disponíveis e que 
estão sendo normalmente utilizadas por outras economias. mas também o próprio desenvolvimento da ciência è da pesquisa tecnológica na área.

Cientistas e empresários importantes têm defendido o uso de plantas transgênicas pela agricultura, bem como a continuidade e intensificação das pesquisas nesta área do conhecimento humano. Políticos têm se colocado nos dois lados do espectro: alguns se manifestam contra e outros, a favor do uso dos transgênicos, refletindo a divisão de opiniões na sociedade. Recentemente um destacado membro da hierarquia da Igreja Católica no Brasil manifestou-se no sentido de considerar os transgênicos na mesma categoria do trabalho escravo, alinhando-o, pois, entre os males que assolam a agricultura, bem como outros setores da economia do país.

Neste trabalho, seus autores se propõem a discutir alguns elementos que parecem rclevantes, para que a sociedade, por meio de suas instituições, possa refletir e, quiçá, decidir acerca de dois aspectos fundamentais no que diz respeito aos transgênicos. Primeiro, sobre a política nacional de pesquisa dos organismos geneticamente modificados. Segundo, sobre o uso de tecnologias, atualmente disponiveis para o agronegócio, que usam algum tipo de transgênicos. Estes serão, portanto, os fundamentais pontos de reflexão e de discussão sobre os quais se debruçam os autores deste estudo, cada qual por um viés diferenciado, tendo em vista os aspectos econômicos, os aspectos juridicos c os aspectos éticos que compõem o grande e principal entorno do tema sob análise. Sem dúvida nenhuma, a possibilidade desta análise --.- assim triangularmente desenhada - acerca da liberação dos organismos geneticamente modificados (OGMs) no ecossistema, faz pressupor um anterior estudo de certas questões circundantes, necessárias à completa intelecção deste assunto tão intrincado. Com efeito, não se pode falar em OGMs sem antes conhecer aspectos relacionados à genética e à ecologia (ramos da biologia que darão a pressuposta sustentação às subseqüentes conclusões).

As premissas, sumariamente descritas nos parágrafos anteriores, organizarão minimamente o fundo de conhecimento necessário que admitirá, depois, se adentrar no intrincado arcabouço jurídico que foi sendo formado, por força de 
várias intervenções e de forma até muito veloz, ${ }^{\prime}$ pela intervenção do Estado em suas três esferas de Poder: o Legislativo, enquanto órgão responsável pela criação das normas jurídicas, ou seja, o órgão que expressa a vontade da nação brasileira, determinando condutas aos seus súditos e prevendo sanção e penalidades, àqueles que não se portarem de acordo com as determinações referidas; o Executivo, enquanto órgão responsável pcla efetivação das políticas determinadas pelo Legislativo e pela execução e administração das condições necessárias para o fiel cumprimento das determinações legais e, por fim, o Judiciário, órgão que analisa as condutas dos jurisdicionados e que tem a incumbência de determinar a aplicação das sanções definidas pela lei, sempre que houver descumprimento de seus preceitos.

Em um Estado Democrático de Direito, como é o caso do Brasil, a atuação dos três órgãos do Poder Político, ou, se ainda se preferir, das três esferas de atuação do Estado, deve se pautar, acima e, sobretudo, pelos ditames da Constituição Federal, vontade política expressa pelo poder originário emanado do povo e que, no que concerne ao tema deste estudo, determinou regras claras e diretas a respeito da conduta a ser seguida na regulamentação, na execução e no julgamento de questões atinentes à política ambiental tendente à manutenção de um meio ambiente equilibrado e sadio. São considerações deste viés, pois, que levaram os autores do presente estudo à pesquisa-casada dos distintos ângulos da mesma questão, sob a intenção de oferecer, ao leitor e ao crítico, o percurso interdisciplinar que o tema obrigatoriamente persegue.

O presente estudo estará organizado da seguinte forma, tendo em vista o preambular projeto de desenvolvimento das pesquisas, até as finais conclusões: a) as considerações acerca do estado da arte, sob o viés jurídico, da regulamentação e autorização de uso dos OGMs formarão o primeiro dos itens deste estudo; b) as considerações, sob o viés econômico, da pesquisa e do uso dos OGMs formarão o segundo dos itens deste estudo; c) as considerações de caráter ético, relacionadas ao uso dos OGMs, comporão o terceiro dos itens; d) finalmente, as conclusões resumem e interligam as três formas de pensar o objeto do estudo. Já os aspectos relacionados à

I. Ĺm caráter até certo ponto profético, manifesta-se JOSEPH-ENRIC REBÉS I SOLÉ: "El carácter tradicionalmente subalterno del derecho respecto las exigencias sociales, a las cuales sigue en un proceso de regulación normalmente lento, tal vez se verá obligado en el siglo XXI a adoptar un ritmo distinto de previsión que exija una constante adecuación." (Breves reflexiones sobre el derecho y los previsibles avances de la biotecnología médica. Congreso de Acudemias Iberoamericanas de Derecho (1998). Córdoba: La Academia, 1999, p. 975) 
genética e à ecologia estarão alinhados em outro estudo que se encontra em anexo a estu artigo. ${ }^{2}$

I. Do direito: o arcabouço juridico que se forma diante da introdução gradual dos organismos geneticamente modificados no dia a dia da sociedade brasileira.

Antes da promulgação de nossa última Constituição, o Brasil já dispunha de normas relativas a uma Política Nacional do Meio Ambiente consubstanciada na Lei n. 6.938/1981, lei esta que foi recepcionada pela Constituição Federal de 1988. Com efeito, conforme se afirmou anteriormente, o Poder constituinte originário não se encontra limitado por nenhuma norma jurídica anterior a sua manifestação, mas ele pode muito bem optar por recepcionar as normas pré-existentes que, entretanto, subordinam-se a seus comandos, uma vez que a Constituição Federal é a norma maior de todo ordenamento jurídico.

Quando uma Constituição é promulgada e entra em vigor, seus ditames assumem a posição mais elevada em uma hierarquia normativa, sendo impossível a qualquer lei, anterior ou posterior, limitá-la ou modificá-la. Quer isto significar que quando uma lei qualquer contraria a Constituição Federal, uma de duas coisas acontece, obrigatoriamente: ou esta norma jurídica que contraria a Constituição era anterior a ela e, neste caso, ela deixa de existir, sendo revogada pela lei que the é superior ou esta norma, que tem a aparência de ser jurídica, se mostra contrária à Constituição que a antecedeu no tempo, quando então será tida como uma norma inconstitucional e, consequentemente, nula de pleno direito. Vale dizer: em ambas as possíveis situações as normas deixam de ter validade. Na primeira hipótese, a norma que era válida perde a sua juridicidade por revogação, uma vez que tenham se alterado as condições sociais e a vontade política por ela expressa. Na segunda hipótese, a norma jurídica nunca foi válida e não chegou a adquirir juridicidade justamente porque contrariou aquela vontade política maior consubstanciada no poder constituinte originário. Em um e em outro caso a conseqüência jurídica é a mesma: a colocação daquela norma para fora do mundo jurídico.

Mas não foi o curso normativo antes descrito o que aconteceu com a

2. $U$ referido anexo contém um estudo sobre o assunto - elaborado especialmente para esta finalidade - assinado por Gustavo Ferraz de Campos Mônaco, recomendando-se igualmente a sua leitura. 
Lei n. 6.938/1981. Com efeito, em seu art. $8^{\circ}$, inciso II. a Lei que cria o Conama (Conselho Nacional do Meio Ambiente) determina a realização de estudos atinentes às possiveis conseqüências ambientais de projetos públicos ou particulares, inclusive com a requisição de informações e provas pertinentes. Pode-se enxergar, neste dispositivo, a previsão de um verdadeiro estudo de impacto ambiental (EIA), mas que estava limitado às hipóteses em que o Conama julgasse necessária a realização de tal estudo. Foi a Constituição Federal, no entanto, que deu um passo além, retirando dos órgãos administrativos e/ou consultivos a possibilidade de deliberarem discricionariamente a respeito da realização do EIA. ${ }^{3}$ Com efeito, o inciso IV do $\S 1^{\circ}$ do art. 225 da CF é bem claro quando diz que incumbe ao Poder Público "exigir, na forma da lei, para instalação de obra ou atividade potencialmente causadora de significativa degradação do meio ambiente estudo prévio de impacto ambiental, a que se dará publicidade" Como já antes mencionado, este dispositivo deixa ao prudente arbítrio do Poder Judiciário a colmatação de significância das palavras 'potencialmente' e 'significativa'

Relativamente ̀̀ exegese das expressões 'potencialmente' e 'significativa' manifestou-se o plenário do Supremo Tribunal Federal, em julgamento paradigmático e por unanimidade, a respeito da inconstitucionalidade de um dispositivo da Constituição do Estado de Santa Catarina que dispensava o estudo prévio de impacto ambiental em hipóteses de áreas florestadas ou objeto de reflorestamento para fins empresarias. Neste julgamento, então. ficou assentada a idéia de que a expressão 'na forma da lei' contida no art. $225, \S 1^{\circ}$, inc. IV da CF diz respeito à forma de realização do EIA, a seu conteúdo e, não, quanto às hipóteses de sua eventual dispensa. ${ }^{4}$

Fixada uma posição jurisprudencial, assistiu-se à promulgação da Lei n. $8.974 / 1995$ que procurava regulamentar os incisos II e V do $\S 1^{\circ}$ do art. 225 da Constituição Federal, relativamente à preservação da diversidade e integridade do patrimônio genético nacional, estabelecendo critérios para a fiscalização das entidades

3. Como salienta Eliana MARIA GotiveIa FONTES, quando se refere à introdução das culturas transgênicas, "agora, estamos introduzindo uma nova técnica na agricultura, com a conscientização de que esse impacto deve ser avaliado anteriormente ao uso da tecnologia" (Questōes sobre biossegurança: Seminário Internacional sobre Direito da Biodiversidade. Revista CEJ, Brasilia, v. 3, n. 8, p. 130 , maio/ago. 1999)

4. STF - Pleno - ADI 1.086-7/SC - Rel. Ilmar Galväo … DJU 16/9/94, p. 24.279. 
dedicadas à pesquisa e à manipulação de material genético, procurando tornar controláveis a produção, a comercialização e o emprego das técnicas, métodos e substâncias que coloquem em risco não só a vida, mas também a qualidade de vida e o meio ambiente que lhe é circundante.

Interessante notar que a Lei, que logo ficou cognominada de Lei de Biossegurança, deixa muito claro em sua epígrafe que está regulamentando apenas os incisos II e V do artigo constitucional relativo ao meio ambiente. Com efeito, além de regulamentar estes incisos, a Lei de Biossegurança autorizava o Poder Executivo a criar uma Comissão Técnica Nacional de Biossegurança (CTNBio), traçando as suas atribuições que foram, no entanto vetadas por sua Excelência, o presidente da República. As razões do veto presidencial, relativamente à colocação da CTNBio no corpo burocrático estatal foram assim justificadas:

A verdade é que a organização de comissão apropriada e a definição de suas atribuições e vinculação deveriam ser objeto de dispositivo legal a ser elaborado oportunamente, à luz dos estudos de reforma do Estado que ora se iniciam.

Ademais, a criação, estruturação e atribuições dos órgãos públicos somente se realiza por meio de projetos de lei de iniciativa privativa do Presidente da República.

Por outro lado, relativamente às atribuições desta CTNBio, a Lei de Biossegurança deixava consignado, $\mathrm{cm}$ seu art. $6^{\circ}$ : também vetado pelo Presidente, que a CTNBio podia:

XVIII exigir, como documentação adicional, se entender necessário, o Estudo de Impacto Ambiental (EIA) e o respectivo Relatório de Impacto no Meio Ambiente (RIMA) de projetos e aplicação que envolvam a liberação de OGM no meio ambiente, além das exigências

5. DO de 06/01/95, p. 345-46. 
especificas para o nivel de risco estabelecidas na regulamentação desia Lei;

O presidente da República, em mensagem enviada ao presidente do Senado Federal para explicar o seu veto, explicou-o como sendo decorrência do veto ao art. $5^{\circ}$. uma vez que não poderia permitir que um dispositivo legal atribuísse competências a um órgão que sequer poderia ser criado. Mas. especificamente com relação ao inc. XVIII do art. $6^{\circ}$ da Lei n. 8.974/1995, pela simples leitura de seu teor e pela confrontação com a jurisprudência da Corte incumbida de guardar e zelar pela Constituição Federal, pode-se perceber a sua inconstitucionalidade. Perdeu o legislador, todavia. a oportunidade para especificar a forma e o conteúdo do estudo de impacto ambiental (EIA), como determinava o inc. IV do $\S 1^{\circ}$ do art. 225 da CF

Fm dezembro de 1995, o vice-presidente da República, no exercício da presidência regulamentou o funcionamento e a competência da CTNBio, vinculandoa à Secretaria Executiva do Ministério da Ciência e Tecnologia. Quanto ao estudo de impacto ambiental, o decreto determinava que a CTNBio deveria:

Art. $2^{\circ}[\ldots]$

$X$ emitir parecer técnico prévio conclusivo sobre qualyuer liberação de OGM no meio ambiente, encaminhando-o ao órgão competente;

Percebe-se, portanto, que o Decreto não mais se referia ao estudo prévio de impacto ambiental, referindo-se apenas a um certo parecer técnico prévio conclusivo. Todavia, não se deixava ao alvedrio da CTNBio a possibilidade de dispensar este parecer.

Instalada a CTNBio, passou ela a analisar as hipóteses de liberação de OGMs no meio ambiente. Para tanto, valeu-se de instruções normativas para regulamentar algumas questões que teriam ficado obscuras ou muito genéricas na legislação pertinente a seu funcionamento. Em duas delas, no entanto, a saber, as instruções normativas 3 e 10 (que dispõem sobre a liberação planejada no meio ambiente de vegctais geneticamente modificados - VGM), a CTNBio entendeu por bem regulamentar a exigibilidade do EIA, fazendo-o no seguintes termos: 
Cada proposta será analisada por uma Comissão Setorial Especifica da CTNBio, a qual poderá solicitar o parecer de consultores ad hoc quando considerar necessário. Os proponentes receberão do(a) Secretário(a) us informações sobre datas de quaisquer reuniões. Oito semanas serão, normalmente, necessárias entre o recebimento de uma proposta e as considerações iniciais da Comissão. Os proponentes poderão ser convidados a comparecer às reuniões para responder questões relativas à proposia. O parecer da CTNBio sobre a mesma será enviado à CIBio no prazo de 4 semanas upós a análise. final. Se a CTNBio considerar que a liheração proposta provocará efeito negativo ao meio ambiente, a mesma será enviada ao Ministério do Meio Ambiente, dos Recursos Hidricos e da Amazônia Legal, que poderá exigir o Estudo de Impacto Ambiental . EIA / RIMA, conforme diretrizes estabelecidas na Resolução Conama n. 001/86, que poderá resultar em recomendações sobre condições a serem agregadas à proposta.

Percebe-se, portanto, que ao arrepio da Constituição Federal e da jurisprudência do STF. um órgão administrativo ${ }^{6}$ ligado ao Governo Federal determinou a dispensa do prévio ElA, embora outras vozes afirmassem que já havia um EIA/RIMA naquela consideração da CTNBio sobre o efeito negativo ao meio ambiente, da liberação proposta. Ora, sendo a CTNBio formada por cientistas da mais alta qualificação nacional, é estranho que se exigisse que alguma "empresa" ou instituição do pais fosse especialmente contratada para elaborar um EIA, quando a qualidade de seus técnicos seria, provavelmente, menor que a dos componentes da CTNBio. De todos os processos técnicos analisados pela comissão, o que mais

6. MANOEL GONÇALVES FERREIRA FilHu entende que "a CTNBio é mais do que um mero órgão de assessoramento do Poder Executivo. Está próxima de ser uma autarquia, ou, no estilo mais moderno, uma Agência. Para tanto the falta essencialmente a autonomia financeira" (Parecer. Biotecnologia no Brasil uma abordagem juridica, p. 147) 
polêmica causou foi certamente o relacionado à soja transgênica, até porque este foi, até agora, o único OGM liberado pela CTNBio.

\section{A liberação do plantio e comercialização da soja transgênica.}

A Imprensa nacional noticiava que, em 16 de setembro de 1998 a CTNBio se reuniria e analisaria o pedido formulado, em junho daquele ano, pela Monsanto do Brasil S/A para tratar de assunto referente à autorização para cultivo e produção de variedades de soja nas quais foi enxertado um gene capaz de suportar a ação nociva da substância química denominada glifosato (round up ready), base para a fabricação de um herbicida criado e comercializado pela própria Monsanto. ${ }^{7}$ As vantagens do plantio destas variedades poderiam ser assim sintetizadas: a plantação de soja round up ready, cujas sementes seriam comercializadas pela Monsanto seria pulverizada com o herbicida a base de glifosato. também ele comercializado pela Monsanto, que detém a tecnologia para a produção de ambos. Este herbicida, ao agir, exterminaria todas as espécies de plantas daninhas, mas a soja não pereceria. Ao contrário, livre de competidores no solo irrigado, poderia se desenvolver de forma mais eficiente.

A CTNBio elaboraria, segundo a imprensa, o parecer técnico prévio conclusivo a que se refere $o$ inciso $X$ do art. $2^{\circ}$ do Decreto $n$. 1.752 , não apenas

7. Fátima OlıVeira (Afinal, qual è mesmo o suave veneno dos transgênicos? O Mundo da Saúde, São Paulo, v. 23, n. 5, p. 282, set./out. 1999) afirma que "se há uma plantação de soja que exige um tipo específico de inseticida fabricado por uma única empresa, fica óbvio que se criou um privilégio econômico. (...) Do ponto de vista da ética das relações estritamente comerciais, isso é inadmissivel, pois cria consumidores escravos!" A afirmação da autora é, claramente, exagerada, uma vez que ela nega a lógica econômica de todo o sistema de patentes prevalecente nas economias de mercado. Não há nenliuma obrigação de qualquer agricultor usar sementes que requerem um determinado herbicida patenteado. Se ele quiser, e julgar vantajoso, usar aquele tipo de semente (tecnologia), terá que usar um certo herbicida até que surjam novos produtos substitutos ou até que a patente caduque. IGN $Z$ Z CONCEIÇÃO NINNI RAMOS. por sua vez. afirma tratar-se de "modalidade de venda casada de semente com o herbicida, totalmente contrária à prática consumerista prevista em nosso código" (Transgênicos: OGMs. Revista de Direito Difusos. São Paulo, v. 2, n. 8, p. 1.061, ago. 2001). Ora, quase todos os chamados "pacotes tecnológicos" recomendados pelas instituições de pesquisa trazem algum tipo de casamento de práticas culturais. A famosa "revolução vurde", que retirou milhões de pessoas do estado de fome, especialmente na Ásia, trouxe para os agricultores a exigência de uso de fertilizantes químicos e defensivos como condição necessária para o uso de variedades mais produtivas. Qualquer agricultor pode não usar as sementes mais produtivas de uma nova tecnologia. Infelizmente. a lógica de estar numa economia competitiva pode condená-lo a ter rendas mais baixas que seus pares. qué a adotam. Sua liberdade, no entanto, é totalmente assegurada na escolha de qual tecnologia será utilizada. 
autorizando o plantio e a comercialização da soja transgênica, como dispensando a Monsanto do Brasil de proceder ao estudo de impacto ambiental determinado pela Constituição Federal, com base na sua Resolução Normativa n. 10. Diante da eminência de uma decisão deste tipo, que não só liberasse o plantio e a comercialização, mas que também passasse ao largo de determinações legais e constitucionais, como vinha sendo noticiado pelos meios de comunicação que tiveram acesso a informações privilegiadas. o IDEC (Instituto Brasileiro de Defesa do Consumidor) pleiteou perante o Poder Judiciário, em 14 de setembro daquele mesmo ano (portanto, dois dias antes da reunião), em ação cautelar inominada movida contra a União Federal. que a CTNBio fosse proibida de emitir tal decisão dispensando a apresentação do ElA e do subseqüente relatório de impacto no meio ambiente (RIMA), uma ve\% que não teria competência para tanto. ${ }^{8}$ A liminar perseguida na ação cautelar foi deferida pelo juízo federal paulista que. logo depois considerou ser incompetente para conhecer e julgar a ação. determinando a remessa dos autos à seção judiciária federal do Distrito Federal. onde haveria um juízo que estaria prevento para a análise do caso.

Com efeito, os autos da ação cautelar foram redistribuídos à $6^{\mathrm{a}}$ Vara Federal do Distrito Federal e a liminar anteriormente deferida pelo judiciário federal paulista, cassada. Todavia, posteriormente. o pedido do IDEC foi realizado e a medida cautelar foi novamente concedida. Todavia, neste ínterim, a CTNBio realizou a reunião programada e que fora suspensa pela primeira decisão liminar e liberou o plantio e a comercialização da soja transgênica round up ready em todo o território nacional. No entanto, diante do deferimento de nova medida cautelar, o plantio e a comercialização ficaram novamente proibidos. Ao IDEC uniram-se na qualidade de litisconsortes ativos a ONG Greenpeace e o órgão do Governo Federal Ibama. sendo certo que a Monsanto e a Monsoy também ingressaram na contenda judicial haja vista o seu interesse no resultado prático da demanda, ocupando o lugar de litisconsortes

8. Nusse sentido: BRÁUl.IO FERREIRA DE SOUZA DIAS. Biodiversidade c organismos geneticamentc modificados: desafios cientificos e legais. Meio ambiente, direito e cidadania, p. 72 . Em sentido contrário, entendendo que a lei atribui estu competência à CTNBio, veja-se a série de pareceres solicitados pelas rés, publicados conjuntamente pela ABIA (Associação brasileira da indústria alimenticia) em: AAVV. Biotecnologia no Brasil: uma abordagem juridica (coletànea de pareceres). Dentre os pareceristas. destaquem-se Guido Fernando Silva SOARES, MaNoel Gonçalves Ferreira Filho, Toshio Mlikai, fíbio Ulhôa Coelho. Também: Gina Copola. Os alimentos transgênicos. Revista da Faculdade de Direito de São Bernardo do Campo, São Bemardo do Campo, $\mathrm{v}$ 6, n. 8 , p. I51, 2002. 
passivos, ao lado da União Federal.

$\mathrm{Na}$ prática judiciária, as medidas cautclares visam resguardar o resultado prático de uma ação judicial (pendente ou futura) que adquire caráter principal. Neste caso, a medida cautelar proposta pelo IDEC visava garantir que a soja transgênica não fosse liberada para plantio, nem sequer plantada, para que se pudesse, ao depois, pleitear uma ação civil pública onde o pedido principal viria de ser formulado. Foi o que ocorreu, uma vez que os litisconsortes ativos propuseram uma ação civil pública que, dentre outras coisas pleiteava que se exigisse da Monsanto e do Poder Público o seguinte: (i) realização do EIAJRIMA, em caráter prévio, e com o intuito de se provar que a soja transgênica não causaria danos ao meio ambiente e ao ecossistema equilibrado e (ii) rotulagem de todos os produtos geneticamente modificados, bem como dos produtos que contivessem em sua composição organismos geneticamente modificados.

Relativamente à realização do ElA/RIMA, a Monsanto argumentava que este não era necessário, pois a CNTBio o havia dispensado, uma vez que a empresa teria apresentado uma farta documentaçào em que restaria provada que a soja transgênica seria absolutamente inofensiva ao ecossistema e ao meio ambiente. Em contrapartida, os autores das ações alegavam que a documentação apresentada pela Monsanto referia-se a ecossistemas muito diferentes dos ecossistemas brasileiros onde normalmente há o plantio de soja (regiões Sul e Centro-Oeste), uma vez que tais estudos haviam sido realizados basicamente nos Estados Unidos, Canadá c Argentina, ${ }^{9}$ paises onde não há qualquer controle posterior relativo à comercialização dos produtos geneticamente modificados. ${ }^{10}$

Com referência à questão do locus onde tenha sido realizado o estudo de impacto ambiental é interessante ressaltar a seguinte passagem, extraída da obra de um professor e biólogo brasileiro, ligado à UnB, quando comenta os estudos de Darwin:

9. A posição da Argentina. ressalte-se. poderá acarretar problemas decorrentes da futura juridicização do MERCOSUL e da necessidade de uma certa harmonia legislativa.

10. A respeito das divisões entre os Estados a respeito da liberação de transgênicos (basicamente a posição dos EUA versus a posição européia) veja-se: MARCELO LEITE. OS genes da discóndia: alinkentos transgènicos no Brasil. Parcerias Estratégicas. Brasilia. n.10. p. 179-181. mar. 200।. Ainda: MURILODE Morais e Miranda. Alimentos transgênicos: direitos dos consumidores; deveres do Estado. Revista de Direito do Consumidor. Sào Paulo. n. 39. p. 242. jul./set. 2001. 
... a Terra é um grande mosaico - não há dois puntos na Terra que seja idênticos. Então, não é porque um genoma possibilitou o desenvolvimento de um individuo, num determinado local, que o fará da mesma maneira à prole daquele individuo, se for habitar um local 100 metros adiante ou distante um quilômetro ao sul ou ao norte. Não há garantia nenhuma de mesmo desenvolvimento dos individuos, por causa dessa heterogeneidade espacial."

Embora se possa dizer - acompanhando o raciocínio puramente científico das probabilidades … que 'em ciência não há garantia para nada', os autores da ação alegaram, com base em várias manifestações de alguns membros da comunidade científica, que as condições climáticas, do solo e outras, poderiam causar outras formas de reação à introdução dos OGMs.

Baseados no princípio da precaução, que se encontra consubstanciado não apenas nas conferências diplomáticas e nos tratados e convenções internacionais subscritas pelo Brasil, como também na própria Constituição e na legislação ordinária brasileira, ${ }^{12}$ os autores convenceram o Ministério Público Federal da viabilidade de sua demanda. Nesse sentido, as manifestações do MPF apresentaram-se ao longo do processo como verdadeiras obras de defesa do meio ambiente ecologicamente equilibrado, logrando convencer o magistrado que presidiu aos processos, o qual sentenciou os autos da ação cautelar, finalmente, aos 10 de agosto de 1999 e nos autos da ação civil pública em 26 de junho de 2000. Objeto de recurso, a decisão da medida cautelar foi julgada em apelação pelo Tribunal Regional da la Região, mantidos os termos da sentença. Foram interpostos embargos de declaração contra o acórdão e o

II. BRÁULIO FERREIRA DE SOUZA DIAS. Biodiversidade e organismos geneticamente modificados: desafios científicos c legais. Meio ambiente, direito e cidadania. p. 66 - destaques inexistentes no original compulsado.

12. Para o estudo do princípio da precaução: EvIO MORAIS DA Sil_VA. Os organismos geneticamente modificados e o princípio da precaução como instrumento de proteção ambiental. Boletim do Centro che Esiludos da Procuradoria Geral do Estado de São Paulo, São Paulo, v.26, n. 6, p. 417 e seguintes, jul.iago. 2002. Ainda, F. PENAlva DA Silva. O princípio da precaução e a biossegurança de transgénicos. Revista de Direitos Difusos, São Paulo, v. 4, n. 17. p. 2341 -71, jan./fev. 2003. 
processo foi objeto de Recurso Especial, distribuído ao STJ sob o n. 505.37I, em 7 de abril de 2003, estando, no presente momento, conclusos ao ministro relator. Peçanha Martins, já com parecer do Ministério Público Federal.

As decisões judiciais que proíbem o plantio e a comercialização de soja geneticamente modificada encontram-se dotadas de plena eficácia jurídica, mas o que se tem visto, no entanto, é a sua não efetividade, uma vez que os comandos que nelas se contém não encontraram eco no mundo real, nem encontraram respeito por parte daqueles que a ela estavam obrigados, os quais parecem ter preferido se submeter ao eventual pagamento das multas impostas pelos tribunais e plantar a soja round up ready. No âmbito legislativo, por sua vez, o tema contou com o beneplácito do governo e foi objeto de duas medidas provisórias, ambas convertidas em lei e que procuraram regulamentar a comercialização da soja transgênica que, não obstante a decisão judicial que proibiu o plantio, foi colhida nos anos de 2003 e 2004. Assim, a MP 113, convertida na Lei n. 10.682/2003, procurou determinar a forma de colheita, estocagem e comercialização da soja transgênica referente à safra de 2003. Já a MP 131, convertida na Lei n. 10.814/2003. determinou as regras relativas à safra de 2004 .

Contra a MP n. 131 foram propostas três ações diretas de inconstitucionalidade: ADI 3011 (proposta pelo PV), ADI 3014 (proposta pela Contag

Confederação Nacional dos Trabalhadores na Agricultura) e ADI 3036 (proposta pelo PFL). Todas estas MPS foram extintas por despacho da relatora, ministra Ellen Gracie, em razão de não terem sido aditadas quando da conversão da MP em Lei. No entanto, o procurador geral da República propôs a ADI 3109 contra a Lei n. 10.814/2003, originada da MP 131. Os argumentos da ADI vão no sentido de que a Lei autoriza o plantio da soja transgênica no território nacional, sem que se tenha, ainda, realizado o FIA determinado pela Constituição Federal e mandado realizar pclo Poder Judiciário. No presente momento. o processo encontra-se distribuído ao ministro Gilmar Mendes. tendo sido dada vista do processo ao procurador geral da República após terem sido juntadas aos autos as manifestações da Advocacia Geral da União e do presidente do Congresso Nacional. Além disso, a Associação Nacional de Biossegurança requereu o seu ingresso no pleito. na qualidade de amicus curiae.

A ser mantida a jurisprudência do STF a respeito do EIA/RIMA, muito provavclmente a Lei n. 10.814/2003 será julgada inconstitucional na parte em que dispensa o prévio estudo de impacto ambiental. Por determinação do presidente do STF a ADI será submetida pelo relator a julgamento nos termos do art. 12 da Lei $n$. 
9.868/1999, que disciplina o julgamento das medidas provisórias com pedido de medida liminar cujo objeto seja relevante para a ordem social e a segurança jurídica, como é o caso do presente feito.

Outra questão muito debatida ao longo da mencionada pendenga judicial foi o pedido do IDEC para que os produtos que contivessem organismos geneticamente modificados fossem rotulados, em cumprimento às determinações do Código de Defesa e Proteção do Consumidor. Segundo as razões que fundamentaram tais ações, a não rotulagem destes produtos poderia levar, por exemplo, vegetarianos a ingerirem genes animais, judeus ou muçulmanos a ingerirem carne de porco, para que se fique apcnas em exemplos que afetam a consciência moral ou religiosa dos indivíduos. ${ }^{13}$ Até a propositura das ações, os produtos que contivessem OGMs em sua composição ou aqueles que fossem, tout court, OGMs, não recebiam qualquer espécie de signo distintivo, pois não havia norma jurídica federal que disciplinasse especificamente esta questão. ${ }^{14}$ Todavia, a determinação judicial foi no sentido de ser absolutamente necessária esta providência como forma de se dar cumprimento ao Código de Defesa do Consumidor, no que concerne ao direito à informação que assiste todo e qualquer consumidor. ${ }^{15}$

Certamente deve ser o consumidor quem deva decidir se vai ingerir alimentos modificados em sua composição genética, ou se vai optar por produtos tradicionais, ainda que a um custo econômico mais alto ou ainda que com qualidade ou estética um pouco pior. Desta forma, o Decreto n. 3.871, de 18 de julho de 2001

13. Como informa EDGaR MOREIRA (Alimentos transgênicos e proteção do consumidor. Biodireito: ciência da vida, os novos desafios, p. 235), há fortes indícios de que produtos, mormente os importados, estejam sendo vendidos no Brasil sem a indicação de conterem material geneticamente modificado em sua composição.

14. Todavia, no Estado de São Paulo foi promulgada lei estadual que regulamentava a questão, uma vez que a competência deste ente federativo, ainda que concorrente com a da Federação, pôde ser exercida de forma genérica ante a falta de lei federal neste sentido. Veja-se: ANADIL ABUjADRA AMORIM. Competência legislativa para a rotulagem dos alimentos transgênicos: direito à informação e a lei estadual $n^{\circ}$ 10.467/99. Boletim do Centro de Estudos da Procuradoria Geral do Estado de São Paulo, São Paulo, v.24, n.6. p.657-661, nov./dez. 2000. Do ponto de vista teórico a respeito da repartição de competências entre os entes federativos. veja-se, por todos, o parecer já citado de MANOELCONÇALVES FERREIRA FILHO, passim.

15. A Monsanto, no entanto, argumenta que "não se pode impor um sistema que distorça a realidade do produto, que diga que ele tenha uma alteração genética, quando, na realidade, não se alterou o produto final em sua essência". O argumento, então, era no sentido de que "sendo o produto o mesmo, não tem o que informar ao consumidor" (Cf. SIMONE YAMAMURA. Aspectos sócio-jurídicos sobreo plantio e consumo de transgênicos. Revista Juridica, Campinas, v. 18, n. 2, p. 76. 2002). 
determinou a rotulagem de todos os produtos que contivessem, em sua composição, mais do que 4\% de OGMs. Esta percentagem, dizia o decreto, devia ser de ingredientes adicionados de forma proposital, ou seja. sabendo o seu fabricante ou fornecedor, que se tratava de matéria modificada geneticamente. E mais, determinava que quando o produto fosse obtido com a mistura de vários ingredientes. a rotulagem só seria necessária se pelo menos um dos ingredientes superasse o nível de $4 \%$ determinado no decreto.

As organizações ambientalistas e aquelas de defesa do consumidor continuam a protestar, pois entendem ser necessário que a rotulagem atingisse também os produtos vendidos a granel ou in natura, além de pleitearem a informação da origem do gene adicionado ao produto tradicional, justamente para que se evitassem aqueles casos, antes exemplificados, de ingestão de gene animal por um vegetariano que consumisse soja ou qualquer outro vegetal modificado, ou de um judeu que consumisse gene suíno ao ingerir um outro animal qualquer, por exemplo. Nesse sentido, a ABIA (Associação Brasileira das Indústrias de Alimentação). consciente da inevitabilidade da aplicação do Código de Defesa do Consumidor aos alimentos transgênicos, passou a defender a rotulagem, muito embora tivesse movido uma açăo direta de inconstitucionalidade (ADI) contra a já mencionada lei paulista que determinara a rotulagem destes alimentos. ${ }^{16}$ O Decreto 4.680. de 24 de abril de 2003, que revoga expressamente o decreto anterior. determinou que todo alimento com mais de $1 \%$ (um por cento) de sua composição formada por OGMs deva ser rotulado com os dizeres específicos, levando ainda um símbolo criado por portaria do Ministério da Justiça, além de se determinar a indicação da origem do gene transportado para o OGM. ${ }^{17}$

Encontra-se, atualmente, em tramitação no Congresso Nacional um Projeto de Lei (PL-240I/2003) de autoria do Executivo. Tal projeto já foi aprovado pela Câmara dos Deputados e encontra-se. no presente momento, aguardando designação de relator no seio do Senado Federal. Se vier a ser aprovado, este Projeto revogará a Lei n. 8.974, de 5 de janeiro de 1995, a atual Lei de Biossegurança, uma

16. Cf. Jorge Alberto Quadros CARvalho Silva. Alimentos transgênicos: aspectos ideológicos, ambientais, econômicos, políticos e juridicos. Biodireilo: ciência da vida. os novos desafios, p. 343 .

17. Restou de fora do Decreto, no entanto, norma explicita relativa à indicação de tal circunstância em cardápios de restaurantes ou lanchonetes, como já propugnara EDGAR MORERA (Alimentos transgênicos e proteção do consumidor. Biodireito: ciência da vida, os novos desafios, p. 235). 
vez que seus dispositivos procuram regulamentar, de outra forma, as mesmas matérias tratadas na lei vigente. Importa registrar agora, e a este respeito, que o Projeto apresentado pelo Executivo acabou sendo desvirtuado durante a sua discussão e votação na Câmara dos Deputados, muito em função de pressões exercidas por grupos parlamentares ligados aos movimentos ambientalistas e religiosos. Este fato, aliado à troca do relator, em virtude da designação do deputado Aldo Rebelo (relator original) para compor o Ministério, acabou por retirar a sistematicidade do Projeto aprovado que passa a ser, em conseqüência, um Projeto conflituoso, lacunoso e, por vezes, até mesmo contraditório. Caberá ao Senado Federal, portanto, a tarefa de tentar reorganizar as previsões normativas da legislação projetada.

Encerrando esta exposição do estado da arte, relativamente aos aspectos jurídicos (legais e judiciais, principalmente) do assunto pertinente aos OGMs, talvez fosse conveniente organizar um quadro cronológico com a indicação desses principais fatos até aqui assinalados. É o que segue:

\begin{tabular}{|c|c|}
\hline Ano & Ocorrência \\
\hline 1981 & $\begin{array}{l}\text { Promulgada a Lei n. } 6.938 \text {, de } 31 \text { de agosto de } 1981 \text {, que previu estudo de } \\
\text { impacto ambiental em casos determinados pelo CONAMA (art. } 8^{\circ} \text {, inc. II) }\end{array}$ \\
\hline 1988 & $\begin{array}{l}\text { Promulgada a Constituição Federal, que previu o estudo de impacto ambiental } \\
\text { em hipóteses de potencialidade degradante do meio ambiente (art. } 225, \S 1^{\circ} \text {, } \\
\text { inc. IV) }\end{array}$ \\
\hline 1994 & $\begin{array}{l}\text { Julgamento da ADI } 1.086-7 / \mathrm{SC} \text {, por unanimidade do Plenário, relativamente } \\
\text { a dispositivo constitucional estadual que limitava o alcance do art. } 225, \S 1^{\circ} \text {, } \\
\text { inc. }[\mathrm{V}, \mathrm{CF}\end{array}$ \\
\hline 1995 & $\begin{array}{l}\text { Promulgada a Lei n. } 8.974 \text {, de } 5 \text { de janeiro de } 1995 \text {, que previu a criação e a } \\
\text { competência da CTNBio, mas que teve tais artigos vetados pelo Presidente da } \\
\text { República }\end{array}$ \\
\hline 1995 & $\begin{array}{l}\text { Promulgado o Decreto n. } 1.752 \text {, de } 20 \text { de dezembro de } 1995 \text {, que criou a } \\
\text { CTNBio e estabeleceu a sua competência }\end{array}$ \\
\hline 1998 & $\begin{array}{l}\text { Proposição das ações cautelar e civil pública pelo IDEC e outros contra a } \\
\text { União Federal e outros, com concessão de medida liminar }\end{array}$ \\
\hline 1999 & $\begin{array}{l}\text { Sentença da medida cautelar, mantendo a proibição dos transgênicos, } \\
\text { enquanto não se realizar o EIA/RIMA }\end{array}$ \\
\hline 2000 & Sentença da ação civil pública, determinando a realização do ElA/RIMA \\
\hline 2001 & Publicação da ementa do TRF $/ 1^{3}$ região no DJU de $15 / 3 / 2001$, p. 84 \\
\hline 2001 & $\begin{array}{l}\text { Decreto } n .3 .871 \text { determina a rotulagem de alimentos com mais de } 4 \% \text { de } \\
\text { OGMs }\end{array}$ \\
\hline 2003 & Entrada do recurso especial no STJ \\
\hline
\end{tabular}




\begin{tabular}{|c|l|}
\hline 2003 & $\begin{array}{l}\text { Edição de duas medidas provisórias convertidas em lei para regulamentar a } \\
\text { colheita da safra de } 2003 \text { e } 2004 \text { da soja transgência round up ready }\end{array}$ \\
\hline $\mathbf{2 0 0 3}$ & $\begin{array}{l}\text { Decreto n. } 4.680 \text { determina a rotulagem de alimentos com mais de 1 \% de } \\
\text { OGMs }\end{array}$ \\
\hline $\mathbf{2 0 0 3}$ & $\begin{array}{l}\text { Apresentação, pelo Poder Executivo, do Projeto de I.ei n. 2401/2003 que } \\
\text { dispõe sobre uma nova Lei de Biossegurança }\end{array}$ \\
\hline $\mathbf{2 0 0 4}$ & $\begin{array}{l}\text { Aprovação, na Câmara dos Deputados, do Projeto de Lei n. 2401/2003, após a } \\
\text { substituição do relator original da matéria e da aceitação, pelo novo relator, de } \\
\text { inúmeras emendas que desvirtuaram o projeto. }\end{array}$ \\
\hline $\mathbf{2 0 0 4}$ & ADI 3109. contra a Lei n. 10.814/2003, que dispensa EIA/RIMA \\
\hline
\end{tabular}

2. Da economia: o mercado e a introdução dos organismos geneticamente modificados

Desde que a Monsanto introduziu a soja resistente ao glilosato, ela começou a ganhar enorme vantagem econômica sobre a indústria química que produzia herbicidas para o cultivo tradicional da cultura ${ }^{18}$ Esta indústria é, principalmente, dc origem europeia. Coincidentalmente a maior reação ao uso e à pesquisa com transgênicos veio daquele continente ${ }^{19}$ Inúmeras ONGs e outras instituições nacionais se posicionaram, imediatamente, contra a tecnologia. Isto sugeriu a alguns ${ }^{20}$ que aquelas indústrias poderiam ter interesse em financiar essas reações a fim de ganhar o precioso tempo nccessário para atualizar-se tecnicamente e poder competir com a multinacional americana. Infelizmente, estas conjunturas não podem ser testadas (no sentido de coleta de evidências) embora fiquem os questionamentos. $^{21}$

A estratégia dos grupos que se opõe aos transgênicos parece ter sido a

18. "No Brasil. dados da consultoria Kleffmann \& Partner indicam que, entre 1998 e 2003, o consumo de herbicidas de Basf. Bayer, Cingenta, DuPont c Dow caiu $42 \%$ para a soja no Rio Grande do Sul, enquanto o de glifosato cresceu mais de 10\%". (Ideologias e interesses alimentam a polêmica dos transgênicos. O Estado de São Paulo, 07/03/2004, p. A13)

19. Deve-se dizer que o primeiro caso de relativo sucesso no uso de técnica de engenharia genética na agricultura aconteceu na Bélgica, no inícıo dos anos setenta, com a produção de uma variedade de fumo capaz de matar um inseto predador da planta.

20. CÂNDido VacCarezza. "Transgênicos: uma conquista da ciëncia" Pronunciamento na Assembleia Legislativa de São Paulo em 05:12i2003, publicado no site do Diretório Nacional do PT, www.pt.org.br/site/artigos

21. FRANCISCO GRAZIANO. em artigo sobre transgênicos publicado pelo O Estado de São Paulo. $\mathrm{cm}$ 16/03/04, p. A2. pergunta: Afinal, qu'm financia o Gre'npeace? 
de usar possíveis dubiedades da lei para postergar, com auxílio da reconhecida morosidade dos nossos processos judiciais e legislativos, a sua eventual adoção no Brasil. Este caminho é legítimo para qualquer grupo de interesse e têm apresentado grande sucesso neste caso, a ponto de o cientista Aluizio Borem, da Academia Brasileira de Ciência e que também integra a Sociedade Brasileira de Genética e a Sociedade Brasileira de Biotecnologia, afirmar que desde 1998, os pesquisadores aguardam o final do confronto entre o Ministério do Meio Amhiente e a CTNBio. para dar continuidade a projetos estratégicos como, por exemplo, o do feijão resistentc a virus desenvolvido pela Empresa Brasileira de Pesquisa Agropecuária (EMBRAPA), que beneficiaria, principalmente, os pequenos produtores. ${ }^{22}$ Nas palavras de Elibio Rech, pesquisador da Embrapa, o atraso foi irreparável. ${ }^{23}$

Embora o relativo atraso no uso dos transgênicos pelo agronegócio no Brasil possa não significar grandes perdas para a nossa economia no curto prazo, os atrasos no uso destes organismos na pesquisa são, indubitavelmente, prejudiciais à economia e ao próprio desenvolvimento das ciências no longo prazo. O maior prejuizo está, certamente, nas limitações ao desempenho da pesquisa no pais. Por essa razão, as considerações qui se seguem estão divididas em duas partes: na primeira, tecemos considerações sobre os efeitos da controvérsia sobre a pesquisa c ciência nacionais; na segunda, endereçamos os problemas associados à proibição do uso de transgênicos no agronegócio do país.

Os transgênicos e a pesquisa agropecuária e do agronegócio.

Talvez o mais constrangedor dos temas elevados à discussão, na pauta dos OGMs, seja este que diz respeito à pesquisa agropecuária e do agronegócio. Por isso mesmo. inicialmente talvez se devesse perguntar qual o potencial impacto da tecnologia transgênica no avanço das ciências aplicadas, em geral, e no agronegócio, em particular.

É sabido que o uso de instrumentais cientificos no desenvolvimento de novas tecnologias na agricultura tem gerado resultados naturalmente imprevisiveis, o que têm mudado profundamente a história dos povos. Um dos casos mais conhecidos

22. Cláudia Izique. Lei polêmica. Revista Pesquisa FAPESP. n. 97, março/2004, p. 20.

23. Idem, ibdem. 
na literatura é o que relata a visão prevalecente, até a algum tempo no século XIX, que dizia que a humanidade estava ladada a extinguir-se em fome generalizada. uma vez que as populações cresciam segundo uma progressão geométrica. enquanto a produção de alimentos crescia segundo uma progressão uritmética (visão Malthusiana). A convivència da humanidade com estas visões catastróficas, na verdade vem desde os tempos bíblicos.

$\mathrm{Na}$ visão sintetisada por Thomas Malthus. a única maneira que teria a humanidade para conquistar niveis razoáveis de nutrição, seria por meio de rigorosos programas de controle da natalidade. Até a época de Malthus, eram extremamente rudimentares os conhecimentos científicos aplicáveis à produção. conservação e transformação da agropecuária e da pesca, o que gerava. conseqüentemente. a visão determinista de que a disponibilidade de alimentos cresceria sempre menos que o crescimento populacional. Os avanços da ciência em geral - da física, química. biologia e, principalmente, da genética - permitiram demonstrar que aquele tipo de visão catastrófica não resistiria aos fatos. Diversas tecnologias foram geradas e utilizadas para o agronegócio e permitiram alimentar um número de habitantes no planeta, como nunca imaginado por Malthus.

No caso particular da genética e, conseqüentemente, no caso especifico relacionado ao melhoramento de plantas e animais, os avanços do conhecimento no século XX foram espetaculares. Isto não impediu, no entanto, que visões parciais e distorcidas da ciência, e de seu uso, fossem responsáveis por atrasos no seu desenvolvimento em determinadas regiões ou economias. Um exemplo clássico aconteceu na extinta União Soviética, propriamente à volta dos anos 30 e início dos anos 40. Trofím D. Lysenko, ${ }^{24}$ um biólogo dedicado ao estudo de métodos agronômicos de produção, conquistou a simpatia de Stalin que queria, em sua visão do marxismo, construir um novo homem através de um novo ambiente social. Lysenko usou a orientação doutrinária stalinista então prevalecente para eliminar a concorrência de qualquer cientista que se opusesse à sua liderança mediocre, especialmente os geneticistas que insistiam na visão de que as pessoas, bem como as plantas e os animais, tinham uma carga genética e que a interação desta herança com o meio determinaria o ente final ou produto. Diversos cientistas foram mortos,

24. Ver a este respeito: GEORGE BAILEY, Galileo's children: science. Sakharov, and the power of the slate. New York: Arcade Publishing, 1990, 458 p. 
confinados em campos de concentração ou afastados de seus cargos para que a liderança de Lysenko não fosse contestada. O resultado, infelizmente, foi um enorme atraso na ciência genética da então União Soviética, o que comprometeu uma melhor performance em seu agronegócio, o qual sempre foi bastante medíocre.

O fato é que qualquer nova tecnologia, como acontece em todas as áreas do conhecimento humano, traz consigo riscos de que surjam novos problemas para as sociedades. Não há, por exemplo, como separar o conhecimento e controle sobre a fusão nuclear da possibilidade de algum país construir suas bombas atômicas. Ou . como foi recentemente sugerido - não há como impedir que algum país ou grupo construa uma cadeira elétrica e a use para executar alguém, pelo fato de a humanidade conhecer e poder usar a eletricidade. Importa igualmente registrar que existem, também, efeitos involuntários que decorrem da inegável e indiscutível ampliação do conhecimento humano e de seu uso tecnológico. É o caso, por exemplo, do lixo radioativo gerado pelo uso da energia atômica, na geração de eletricidade. Há países nos quais a energia atômica é a principal fonte geradora de energia elétrica e ninguém pôde convencer sua população a deixar de produzir eletricidade, pela razão simples de existir tal lixo atômico.

Como regra geral se deve indicar que quase toda construção do engenho humano traz consigo algum tipo possivel de mau uso ou, ao menos, de conseqüência ruim em seu uso irresponsável. Praticamente não existe remédio sem contraindicação. Remédios, em geral, têm contra-indicação e ningućm jamais pensou em proibir a pesquisa ou uso de novos medicamentos, uma vez que seu uso irresponsável pode acarretar sérios prejuízos para os usuários. Reflexões assim parecem mesmo levar à conclusão de que, nesta seara, são sempre dois os pesos, ou são duas as medidas. Resta buscar saber porque.

Infelizmente a ciência não pode - como acredita, ou como gostaria que acontecesse, certo segmento de críticos - determinar resultados com certeza. $\mathrm{Na}$ maioria dos casos, as chamadas leis das ciências não passam de regras probabilisticas que indicam o sentido e intensidade da mudança, mas que, só por acaso, provêem resultados exatamente obsurvados na prática. O principio de segurança absoluta que vem sendo exigido por certos segmentos, $৬$ acerca de novos processos ou nova tecnologia não tem qualquer fundamento científico. Este é o caso de certo segmento de ferrenhos opositores dos processos que usam transgenia, yue exibem comportamentos contraditórios quando querem segurança absoluta no trato 
destas tecnologias, mas, por outro lado e curiosamente, não-perguntam (ou nãoperguntaram) sobre a segurança de processos de indução de mutação, ${ }^{25}$ por exemplo. que são extensivamente utilizados por melhoristas de plantas e de animais e que têm. provavelmente, um grau de incerteza bem maior, quanto aos possíveis riscos trazidos pelo seu uso.

Quando um melhorista usa a indução de mulução para aumentar determinada variabilidade genética e conduzir seu processo de seleção, ele não sabe que produto vai encontrar ou, pelo menos, ele não sabe que tipo de produto ou resultado provavelmente encontrará. Ele estará simplesmente estimulando, física ou quimicamente, a mudança em algum gene que poderá ser útil aos seus propósitos. Dito de outro modo, ele sabe que a grande maioria desses novos genes não será útil, e que inúmeras aberrações podem acontecer durante o processo. É possível que algumas dessas aberrações podem. acidentalmente. não ser eliminadas. o que poderá permitir esteja sendo criada alguma característica nova que, eventualmente, poderá ser extremamente prejudicial às pessoas. ou ao ambiente. De fato, mutações em vírus infecciosos acontecem, espontaneamente ou não, e têm sido responsáveis por inúmeras epidemias que causam mortes e sofrimento às pessoas. É. por tudo isso. muito estranho que os opositores da transgenia prossigam exigindo segurança absoluta neste processo de melhoramento de plantas e animais, mas não demonstrem igual preocupação com outros processos que, ao menos potencialmente, poderiam provocar mais e maiores danos, ainda que involuntários, às pessoas e ao ambiente.

Os potenciais danos ambientais certamente ainda devem ser melhor esclarecidos, no caso da transgenia. Em primeiro lugar, é preciso considerar, como recomenda o Professor Miguel Reale, que a Ecologia deve sempre se subordinar à Antropologia. Nas suas palavras "o ecológico não é um valor absoluro, porquanto a preservação do meio ambiente é exercida em função da vida humana". ${ }^{26}$ A esta

25. A indução de mutações é um processo usado por melhoristas de plantas e animais que consiste em expor sementes ou tecidos vivos à ação de raios gama, de outras fontes energéticas ou mesmo a certas substâncias químicas (ditas mutagènicas) provocando mudanças aleatórias nos respectivos seres vivos. Algumas dessas mudanças podem ser fixadas no sentido de tornarem-se parte da carga genética do ser vivo. As mutações geram inümeras mudanças nestes seres, algumas verdadeiras aberrações, que são. em geral, abandonadas (destruidas) pelo melhorista. Algumas poucas são consideradas úteis e passam a fazer parte da variabilidade genética à disposição do pesquisador para que possa atingir seus objetivos de produzir seres ou variedades mais produtivas ou que, de alguma forma, melhoram a vida das pessoas.

26. Miguel Reale. Primado dos valores antropoiógicos. O Estado de São Paulo, artigo publicado em 28 de fevereiro de 2004, p. A2. 
recomendação - advinda das dobras de opinião jurídica das mais abalizadas no contexto nacional - seria possível acrescentar, quiçá, que a pior das agressões ambientais é a pobreza ou a falta de alimentos para as pessoas. Assim, deixar de pesquisar e produzir mais e melhores alimentos, em nome de um possivel - como em todos os métodos da ciência - mas ainda não identificado desequilíbrio biológico, significa aceitar, com certeza, o pior dos desequilíbrios em nome de outro menos importante, que pode nem mesmo acontecer de fato.

\section{O uso comercial de plantas transgênicas.}

Uma das mais eficientes estratégias desenvolvidas por aqueles que se posicionam de forma contrária ao uso comercial e à pesquisa com transgênicos, tem sido fundada na conhecida morosidade da justiça, contando, a seu favor, com a utilização - em tantos casos - das antigas técnicas protelatórias de decisão e avanço, bem como de contínuas exigências de pareceres para comissões e/ou grupos, pareceres estes que sequer poderiam ser definitivos, tendo em vista a subsunção da opinião exarada ao princípio da mera probabilidade. Tudo isso certamente atrasou, e muito, a atividade científica voltada para a pesquisa, em geral, bem como o desenvolvimento do agronegócio, em particular. Por outro lado, e como já se referiu antes. no que diz respeito ao uso comercial dos OGMs, as estratégias levadas a cabo pelos segmentos contrários não foram tão eficientes assim, mesmo porque os agricultores não deram cumprimento às ordens judiciais que proibiam o plantio e a comercialização de soja geneticamente modificada, provavelmente preferindo a sujeição ao pagamento de eventuais multas impostas pelos tribunais, preferindo plantar a soja round up ready.

A verdade é que os agricultores brasileiros contaram com uma importante fonte de recorrência que lhes permitiu buscar sementes geneticamente modificadas, disponiveis em outros países, e o fizeram em grande escala e com significativa intensidade. Fatos assim se deram principalmente no Rio Grande do Sul, Estado brasileiro que conta com condições edafo-climáticas semelhantes às encontradas em algumas regiões da Argentina. Ali, esses agricultores tiveram condições de promover um abastecimento de sementes geneticamente modificadas e as usaram largamente. tudo conforme consta de relatórios de Maria Thereza Pedroso, assessora para a área de política agrícola e agrária da Bancada do Partido dos 
Trabalhadores na Câmara dos Deputados, e publicados no site oficial do PT. ${ }^{27}$ Esses relatórios mostram como os produtores - especialmente os pequenos produtores adotaram a tecnologia que julgaram ser muito mais econômica e eficiente para sua dotação de recursos ou fatores produtivos. Mostram, ainda, a opinião da maioria dos agricultores no sentido de entenderem que a tecnologia é mais segura, tanto em termos ambientais, quanto na preservação da saúde dos próprios agricultores, uma vez que, deste modo, lidariam com menor quantidade de produtos químicos e/ou pesticidas. Mostram, por fim, que a tecnologia deu, a esses pequenos agricultores, um poder de competição em uma área (produção de soja) que estava, cada vez mais, concentrada em propriedades de maior porte ou dimensão.

Os agricultores do centro oeste brasileiro não são diferentes dos gaúchos. De fato, foram os empresários gaúchos os principais responsáveis pela abertura e incorporação do cerrado pela agropecuária brasileira, desde os anos setenta do século passado. Se os agricultores do centro oeste não estão usando sementes transgênicas, isso se explica pela simples razão de que as multinacionais e a Embrapa não têm (ou não ofertaram) sementes transgênicas que fossem adequadas e apropriadas para as condições daquela região, diferentemente do que aconteceu no Estado do Rio Grandes do Sul. Certamente a Embrapa poderia tê-las obtido rapidamente, se isso fosse adequado e vantajoso aos interesses e às condições locais, assim como foi adequado e vantajoso para as condições da região sul.

Outro tipo de considerações que costuma ser feito por aqueles que rejeitam o uso comercial dos OMGs, diz respeito a eventuais poderes monopolistas que empresas transnacionais teriam sobre a agricultura brasileira, no caso de permissão para o uso de tais tecnologias. Do ponto de vista da Economia, considerações deste jaez têm fundamentos bem pouco sólidos. E assim se dá porque a pesquisa agropecuária brasileira é, de longe, a mais adiantada no mundo $\mathrm{em}$ termos de agricultura tropical. Ora, à face de um tal grau de adiantamento, só seria mesmo possível pensar em poderes monopolistas ou de patentes no derradeiro caso de se verem, as nossas instituições de pesquisa, proibidas de desenvolver, satisfatoriamente, pesquisas com transgênicos. Por tudo isso, é razoável pensar que a única maneira de não pagarmos direitos de patente a outros países, em razão da imporłação de técnicas

27. Ver, por exemplo, MARIA THEREZA PEDROSO, Soja Transgênica: impressōes a partir de depoimentos de agricultores do Rio Grande do Sul, novembro de 2003 . em www.pt.org.br/assessor/agrario.htm 
transgênicas, seria por meio do estímulo à pesquisa desenvolvida no nosso próprio país, circunstância esta que é bem diversa daquela pretendida pelos segmentos de oposição que estão tentando justamente dificultar esta mesma pesquisa. É sempre muito interessante notar que técnicos da Embrapa realizaram ensaios de campo com transgênicos, em outros países, como último recurso destinado a manter um mínimo de atualização neste importante campo da pesquisa agropecuária.

A resistência ao uso de transgênicos - visto o assunto ainda por uma angulação alternativa - poderia se revelar como uma espécie de estratégia nacional, já que o Brasil seria um dos únicos grandes produtores de certos produtos da agropecuária sem o uso de transgênicos. Trata-se de uma mensagem inúmeras vezes repetida por representantes comerciais de empresas oriundas de países da Europa que desejavam comprar produtos não-transgênicos do Brasil. De fato, passados cerca de cinco anos, desde que se fala neste nicho de mercado, não se conhece país importador de destaque que esteja disposto a pagar mais por produtos não-transgênicos. Os paises da União Européia estão prestes a liberar a comercialização de transgênicos, com o que a tendência será de não restar nenhum mercado importante que - como se acredita - esteja disposto a pagar mais por aqueles produtos. Em compensação, a indústria européia ganhou precioso tempo para atualizar-se tecnicamente, de sorte que pode, agora, voltar a competir com as multinacionais que mostraram melhor desempenho tecnológico.

A mídia tem registrado uma certa desconfiança a respeito de que os interesses da indústria química européia teriam orientado certos financiamentos a ONGs e a outras instituições brasileiras sob a intenção de ganhar o tempo necessário para que pudessem se atualizar, tecnicamente. Se estas informações corresponderem à verdade, a preocupação é realmente de grande porte, uma vez que tais interesses poderão estar por trás do derrame de recursos que estariam estimulando a reação de instituições de nosso país em desfavor dos transgênicos, inclusive sob o ponto de vista de sua pesquisa, além de aspecto mais aparente que é o de seu uso comercial. O efeito prático final causado por uma reação - eventualmente assim bem orquestrada - à tecnologia tende a sugerir, infelizmente, que os financiadores estrangeiros possam ter, bem claro, este objetivo.

Em desfavor dos OGMs, ainda correm outras políticas de caráter no mais das vezes duvidoso, por the faltarem as suficientes bases cientificas de comprovação. Assim é, por exemplo, que alguns focos de resistência ao uso de 
transgênicos alegam que não aceitam figurar como cobaias no uso de produtos transgênicos, produtos esses que poderiam causar prejuízos à saúde. Existem cartazes distribuídos pela CNBB - ou por sub-grupos que agem em seu nome - que dizem, explicitumente. que o consumo de produtos transgênicos faz mal à saúde das pessoas e ao ambiente. Ora, estas são indicações sem base científica ou são indicações que se baseiam em casos esporádicos e raros de alergia, conforme descritos na literatura. Sem dúvida nenhuma, é patente o viés de mera confrontação contido nestas afirmações, uma vez que não se conhecem alimentos para os quais não haja algum grupo de pessoas que apresente alergia ao seu consumo. Mas certamente, esta estratégia, enquanto recurso à rejeição aos OGMs, é bastante frágil, pois não se trata de não rotular adequadamente os produtos transgênicos, sendo certo que a rotulagem conteria a advertência suficiente para a preservação dos direitos dos grupos alérgicos de não consumirem tais alimentos. ${ }^{28}$

Da ética: o problema ético envolvido na pretensão humana de alterar a ohra do Criador.

Finalmente, um aspecto que permeia todas as discussões sobre transgenia é aquele que está relacionado aos fundamentos éticos da ousadia humana em trabalhar elementos tão íntimos à criação do mundo, tanto sob o ponto de vista de seus desdobramentos na vertente da moral consuetudinária, quanto sob o ponto de vista dos potenciais perigos que um tal tipo de tecnologia pode trazer ao tecido social desenhado pela história da humanidade.

O próprio arco histórico da trajutória humana informa que o passado da Igreja Católica não é exatamente paradigmático, no sentido de servir como excmplo de correção de condutas e de posturas. Ainda hoje, certos grupos da hierarquia da Igreja insistem em manter táticas obscurantistas muito próximas daquelas que a caracturizaram e a estigmatizaram, por muitos séculos. Quem conhece a 'verdade' das coisas do mundo físico por meio da interpretação de um livro sagrado - tal como alguns fundamentalistas muçulmanos, ou tal como os marxistas da extinta União

28. As opiniões que correm contra este tipo de estratégia de argumentaçào contra os transgènicos têm procurado levar a comunidade a refletir acerca de como seria interessante ver o resultado de pesquisa que fosse realizada com membros desses grupos de resistência aos transgênicos, no sentido de se verificar se os que sofrem de diabetes estão se abstendo de tomar insulina produzida, provavelmente. com transgênicos, ainda que se saiba que os tustes com insulina já estcjam concluídos e bem mencionados cm suas rotulagens. 
Soviética, ou mesmo como os católicos que se negaram a aceitar a evolução de Darwin e que proibiram, em certa época, o uso de vacinas - qualquer novo método da ciência será sempre visto como uma contestação àquela 'verdade revilada' Infelizmente tais scgmentos prosseguem achando que tudo sabem e que a ciência não pode modificar a sua visão do mundo. Para sorte nossa, não estamos em um pais onde os fundamentalistas consegucm mobilizar grandes contingentes populacionais e impor suas doutrinas.

Em um ponto de vista esclarecedor sobre o método da ciência, Cláudio de Moura Castro escreve que:

"A inarca do progresso cientifico é justamente o maior peso que vai ganhando a evidência empíric a para decidir yuem está certo. Perdem espaço a fé, a ideologia e a superstição nessa tarefa. Cada vez mais é o teste da realidade que decide... "29

Afirma ainda, que:

“... Contudo, embora a preocupação com os transgênicos não seja descabida, trata-se de um assunto cientifico em que houve retrocesso. Voltumos aos tempos de Darwin. Em vez de vasculhar a evidencia cientifica disponivel, o assunto recende a anticapitalismo, protecionismo europeu equerelas de poder" 30

A ideologização que envolveu o tema transgênicos trouxe retrocessos significativos ao debate mais lúcido que deveria ter acompanhado a implantação de politicas voltadas a seu uso e pesquisa.

29. CLAUDiO DE MOURA CASTRO. Os tropeços da Razão. Revista Veja. ano 36(48):24. 03/12/2003.

30. Idem, ibidem. 
Conclusão

Em recente seminário, apresentado no Departamento de Economia e Administração da ESALQ/USP em Piracicaba, pelo Prof. Steve Pueppke da Universidade de Illinois, USA, e Diretor do National Soybean Research Laboratory (Laboratório Nacional de Pesquisa da Soja), intitulado "Adoption of genetically modified soybeans in the United States: Lessons from the first decade" (Adoção de soja geneticamente modificada nos Estados Unidos: lições da primeira década) foi mostrado o quadro mais recente do estado da arte quanto ao uso da transgenia da soja, naquele país. Da área total cultivada com soja nos Estados Unidos, quase $80 \%$ é do tipo Rounclup Ready. A adoção da tecnologia teve um crescimento impressionante nestes primeiros dez anos, desde seu lançamento, e nenhuma das eminentes catástrofes previstas por alguns ambientalistas se verificou. Relatos de todo o mundo indicam que o aparecimento de plantas resistentes aos princípios ativos sintetizados pelos genes introduzidos não tem acontecido em condições de campo, embora as análises de laboratórios mostrem que eles podem surgir, como acontece com qualquer defensivo utilizado comercialmente.

O princípio da segurança absoluta que muitos estão exigindo dos transgênicos não é exigido ou encontrado em nenhuma outra tecnologia. Além disso. os que combatem os transgênicos estão aceitando, por ignorância ou omissão, outras técnicas que têm mais alta probabilidade de produzir problemas ambientais e/ou para a saúde humana, como a indução de mutações. Esta omissão sugere que interesses de outra natureza estão em jogo, inclusive a estratégia de ganhar tempo para determinadas indústrias conseguirem alcançar, tecnologicamente, a principal detentora de patentes em transgênicos de plantas de alta expressão econômica em todo o mundo.

Realmente. o grande problema do Poder Judiciário é a morosidade e já o dizia Rui Barbosa -.. a demora pode significar a negação da própria justiça, porque a justiça que tarda é falha. A sociedade quer e espera contar com uma prestação jurisdicional qualitativa, eficiente e mais rápida, para ser condizente, enfim, com o tempo em que se vive. Para tanto, é urgente e imprescindivel a superação dos principais pontos do atravancamento da efetividade do direito, pela voz do Judiciário.

O que se vê, infelizmente, como conseqüencia da atrofia do Poder Judiciário e de sua estrutura anacrônica, é o descompasso entre o que prescreve a via 
constitucional de um Estado democrático - que declara dever ser livre, justa e solidária a sociedade, pela erradicação da pobreza e da marginalização e pela redução das desigualdades sociais - e o que na verdade se produz à guisa de efetividade da justiça. Bem por isso, é inegável a existência de situações - infelizmente cada vez mais repetidas - de decisões judiciais que não são cumpridas e que são completamente ignoradas, exatamente como, em tantas das vezes, tem sido ignorada e descumprida a própria lei.

Da mesma maneira como se convencionou, entre nós, dizer que há leis que não pegam, pode-se dizer, hoje, que no Brasil há decisões judiciais que não são para ser cumpridas. Contudo, se a função maior do Judiciário é exatamente a resolução das questões que se estabeleçam entre os membros da sociedade, para inibir e proibir soluções que se produzam pelo viés da força ou da violência, soa completamente inusitada a verificação do desdém e do desrespeito com que decisões judiciais vêm sendo tratadas, uma vez que se cria, na sociedade, a conviç̧ão de que é melhor não cumprir leis e que as decisões das Cortes de Justiça podem ser desconsideradas, se não convier economicamente o seu cumprimento. Tudo isso é fruto de um Poder Judiciário inoperante e enfraquecido, exatamente por ser anacrônico.

No mote da transgenia, algo de urgente reclama ser realizado. O desenho estrutural e organizacional do que se tem hoje -- de um lado a conveniência econômica relativa à continuidade de suas pesquisas sobre OGMs e, de outro, a proibição legal e judicial de seu uso comercial - precisa ser urgentemente revisto, para que se estabeleça, nesta polêmica seara, uma coerência real, com o afastamento de mitos que viabilize admitir uma efetiva verificação de prováveis conveniências. Até porque, apenas assim será possivel garantir o desenvolvimento tão almejado por todos: pelo Estado que poderá se desvencilhar de toda a trama morosamente burocrática que permeia o Poder Judiciário; pelas partes, que poderão obter resposta justa e eficiente para suas demandas; e pelo povo, em geral, que poderá retornar a crer nas instituições nacionais. 
Bibliografia

AAVV. Alimentos geneticamente modificados: segurança alimentar e ambiental (coletânea de palestras). São Paulo: ABIA Associação Brasileira das Indústrias de Alimentação, 2002.

AAVV. Biotecnologia no Brasil: uma abordagem jurídica (coletânea de pareceres). São Paulo: ABIA Associação Brasileira das Indústrias de Alimentação, 2002.

ABRÃO, Paulo de Tarso Siqucira. Biodiversidade, soberania e direitos intelectuais coletivos. Meio ambiente, direito e cidadania. São Paulo: Signus e Nisam-USP, 2002.

AMES, Bruce N.; MAGAW, Renae; GOLD, Lois Swirsky. Ranking possible Carcinogenic Hazards. Science, v. 236, 1987.

AMORIM, Anadil Abujabra. Competência legislativa para a rotulagem dos alimentos transgênicos: direito à informação e a Lei estadual n. 10.467/99. Boletim do Centro de Estudos da Procuradoria Geral do Estado de São Paulo, São Paulo. v. 24, n. 6. p. 657-6I, nov./dez. 2000.

CAPPELli. Sílvia. Avaliação de impacto ambiental e o componente da biodiversidade. Revista Direito Ambiental. São Paulo, v. 6, n. 24, p. 64-101, out/der. 2001.

CASTILHO, Ela Wiecko Volkmer. Patentes de produtos de origem biológica. In: PICARELlI. Márcia Flávia Santini; ARANHA, Márcio Iorio (Coord.). Política de patentes em saúde humana. São Paulo: Atlas, 2001.

CASTRO, Claudio de Moura. Os tropeços da Razão. Revista Veja, ano 36(48):24, $03 / 12 / 2003$.

COPOLA, Gina. Os alimentos transgênicos. Revista da Faculdade de Direito de São Bernardo do Campo, São Bernardo do Campo, v. 6, n. 8. p. 143-56. 2002.

CORDEIRO, Ângela. Prós e contras da liberação de transgênicos no ambiente. In: Biossegurança: uma visão interdisciplinar. São Paulo: Secretaria de Estado do Meio Ambiente. 2001.

DFL NERO, Patrícia Aurélia. Biotecnologia. In: BARRAL, Welber (Coord.). O Brasil e a $O M C$ : os interesses brasileiros e as futuras negociações multilaterais. Florianópolis: Ed. Diploma Legal, 2000.

DIAS. Bráulio Ferreira de Souza. Biodiversidade e organismos geneticamente modificados: desafios científicos e legais. In: Meio ambiente, direito e cidadania. São Paulo: Signus e Nisam-USP, 2002.

FIORILLO, Celso Antonio Pacheco. Tutela jurídica dos alimentos transgênicos no direito brasileiro. Revista de Direito Difusos, São Paulo, v. 2, n. 8, p. 1.007-9, ago. 2001. 
FONTES, Eliana Maria Gouveia. Questões sobre biossegurança: Seminário Internacional sobre Direito da Biodiversidade. Revista CEJ, Brasília, v. 3, n. 8, p. 119,127-131, maio/ago. 1999.

GARRAFA, Volnei. Transgênicos, ética e controle social. O Mundo da Saúde, São Paulo, v. 23, n. 5, p. 286-9. set./out. 1999.

GENOINO, José. Biotecnologia e transgênicos. Pronunciamento na Câmara dos Deputados, em 16.10.2003, publicado no site www.pt.org.br/site/artigos/artigos_int.asp?cod=580

IZIQUE, Cláudia. "Lei polêmica". Pesquisa - FAPESP - ciência e tecnologia no Brasil, n. 97, p. 16-21, mar. 2004.

LFITE, Marcelo. Os genes da discórdia: alimentos transgênicos no Brasil. Parcerias Estratégicas, Brasília, n. 10, p. 174-85, mar. 2001.

MACEDO, Ângela A.M. Produtos transgênicos e o direito a informação do consumidor. Ciência e Direito: Revista Juridica da Fic-Unaes, Campo Grande, v. 1, n. 2, p. 11-34, nov./abr. 1998-1999.

MEIRA, Daniel e Silva. A juridicização dos transgênicos: o fato jurídico da atualidade. Revista da Esmape, Recife, v. 7/8, n. 16-17, p. 209-16, jul./jun. 2002-2003.

MIRANDA, Murilo de Morais e. Alimentos transgênicos: direitos dos consumidores; deveres do Estado. Revista de Direito do Consumidor, São Paulo, n. 39, p. 239-48, jul./set. 2001.

MOREIRA, Edgar. Alimentos transgênicos e proteção do consumidor. In: SANTOS. Maria Celeste Cordeiro Leite dos (Coord.). Biodireito: ciência da vida, os novos desafios. São Paulo: Ed. RT, 2001.

OLIVEIRA, Fátima. Afinal, qual e mesmo o suave veneno dos transgênicos?. $O$ Mundo da Saúde, São Paulo, v. 23, n. 5, p. 280-5, set./out. 1999.

OLTVEIRA, Sabina Nehmi de. Cultura patentiária e alimentos transgênicos. Revista da ABPI, Rio de Janeiro, n. 51, p. 19-23, mar./abr. 2001.

PEDROSO, Maria Thereza. Soja Transgênica: impressões a partir de depoimentos de agricultores do Rio Grande do Sul, novembro/2003, publicado no site www.pt.org.br/assessor/agrario.htm

PELUSO, Lúcia de Toledo Piza. A revolução hiológica e os direitos humanos. Dissertação (mestrado) apresentada à Faculdade de Direito da Universidade de São Paulo, 2001.

PETERS, José. Experiências no Brasil: prós e contras da liberação de transgênicos no ambiente. In: Biossegurança: uma visão interdisciplinar. São Paulo: Secretaria de Estado do Meio Ambiente, 2001. 
PIOLI, Maria Sulema M de Budin. Transgênicos: desafio da era bioindustrial. Meio ambiente, direito e cidadania. São Paulo: Signus e Nisam-USP, 2002.

PRAD(), Daniela Dılmanto. $O$ direito à alimentação e a qualidade dos produtos agroalimentares: a segurança alimentar face aos novos sistemas de produção. Dissertação (mestrado) apresentada à Faculdade de Direito da Universidade de São Paulo, 2001.

RAMOS, Ignez Conceição Ninni. Transgênicos: OGMs. Revista de Direito Difusos, São Paulo, v. 2, n. 8, p. 1057-67, ago. 2001.

REALE, Miguel. "Primado dos valores antropológicos" O Estado de São Paulo, artigo publicado em 28 de fevereiro de 2004, p. A2.

REALF, Miguel. Legitimidade do plantio de soja transgênica (parecer). Revista dos Tribunais, São Paulo, v. 90, n. 789, p. 109-26, jul. 2001.

REBÉS I SOLÉ, Josep-Enric. Breves reflexiones sobre el derecho y los previsibles avances de la biotecnología médica. Congreso de Academias Iberoamericanas de Derecho (1998). Córdoba: La Academia, 1999.

SILVA, Enio Moraes da. Os organismos geneticamente modificados e o princípio da precaução como instrumento de proteção ambiental. Boletim do ('entro de Estudos da Procuradoria Geral do Estado de São Paulo. São Paulo, v. 26, n. 6, p. 4I3-23, jul./ago. 2002.

SILVA, F Penalva da. O princípio da precaução e a biossegurança de transgênicos. Revista de Direitos Difusos, São Paulo, v. 4, n. 17, p. 2341-71, jan./fev. 2003.

SILVA, Jorge Alberto Quadros Carvalho. Alimentos transgênicos: aspectos ideológicos, ambientais, econômicos, políticos e jurídicos. In: SANTOS, Maria Celeste Cordeiro Leite dos (Coord.). Biodireito: ciência da vida, os novos desafios São Paulo: Ed. RT, 2001.

SZKLAROWSKY, Lcon Frejda. Transgênicos: a civilização transgênica e cibernética. Revista de informação Legislativa, Brasilia, v. 37. n. 145, p. 47-53, jan./mar. 2000.

VACCAREZZA, Cândido. Transgênicos: uma conquista da ciência. Pronunciamento na Assembléia Legislativa do Estado de São Paulo, cm 05.12.2003, publicado no site www.pt.org.br/site/artigos/artigos_int.asp?cod $=596$

YAMAMURA, Simone. Aspectos sócio-jurídicos sobre o plantio e consumo de transgênicos. Revista Juridica, Campinas, v.18, n.2, p.64-82. 2002.

ZAMUDIO, Teodora. Protección juridica de las innovaciones: patentes, DOV's. genoma humano, biodiversidad. Buenos Aires: Ad-hoc. 2001. 